\title{
Perhitungan Biaya Satuan (Unit Cost) Berdasarkan Clinical Pathway Bronkopneumonia Anak di RSUP Prof. Dr. R. D. Kandou Manado Periode Juli 2017- Juni 2018
}

\author{
${ }^{1}$ Giza E. E. Arikalang \\ ${ }^{2}$ Edward Nangoy \\ ${ }^{2}$ Christi D. Mambo
}

\author{
${ }^{1}$ Program Studi Pendidikan Dokter Fakultas Kedokteran Universitas Sam Ratulangi Manado \\ ${ }^{2}$ Bagian Farmakologi dan Terapi Fakultas Kedokteran Universitas SamRatulangi Manado \\ Email: gizaarikalang.21@gmail.com
}

\begin{abstract}
Calculation of unit cost could give some information to healthcare policy. Bronchopneumonia is a lung inflammation disease that occurs in around $30 \%$ of babies with high mortality risk. This study was aimed to determine the general depiction of unit cost calculation for bronchopneumonia among pediatric patients at Prof. Dr. R. D. Kandou Hospital according to clinical pathway. This was an observational retrospective study. Samples were obtained by using random sampling as many as 42 samples that fulfilled inclusion criteria. Processed data included patients' demography, treatment, and the average of direct cost calculation. The results showed that the implemented therapy consisted of antibiotic, non-antibiotic, fluid therapy, ancillary laboratory examination, radiology, and ancillary diagnostics. Total cost for drugs was Rp. 8,822,455; laboratory Rp. 28,568,725; radiology Rp. 9,912,400; and ancillary diagnostic examination Rp. $7,110,000$. Compared to the cost covered by BPJS, the hospital had some excess as follows: drug unit Rp. 958,549, radiology Rp. 1,771,517, and ancillary diagnostic examination Rp. 581,852. For ancillary laboratory examination in the hospital, there was a difference as much as Rp. 1,341,276 less than the the BPJS coverage. Conclusion: There was an excess difference within drug unit, radiology, and ancillary examinations for pediatric bronchopneumonia, while laboratorium unit possess lesser cost than BPJS.
\end{abstract}

Keywords: bronchopneumnonia, cost unit

\begin{abstract}
Abstrak: Perhitungan biaya satuan merupakan salah satu informasi masukan dalam pembuatan kebijakan pelayanan. Bronkopneumonia ialah penyakit radang paru yang terjadi pada sekitar $30 \%$ anak balita dengan risiko kematian yang tinggi. Penelitian ini bertujuan untuk mendapatkan gambaran perhitungan biaya satuan pada pasien bronkopneumonia anak di RSUP Prof. Dr. R. D. Kandou berdasarkan clinical pathway. Jenis penelitian ialah observasional retrospektif. Sampel penelitian dikumpulkan dengan metode random sampling berjumlah 42 sampel yang memenuhi kriteria inklusi. Data meliputi data demografi pasien, gambaran pengobatan, dan penghitungan ratarata biaya langsung. Hasil penelitian mendapatkan bahwa terapi yang digunakan ialah antibiotik, non antibiotik, terapi cairan, serta penunjang laboratorium, radiologi, dan penunjang diagnostik. Total biaya untuk obat Rp. 8.822.455, laboratorium Rp. 28.568.725, radiologi Rp. 9.912.400, dan penunjang diagnostik Rp. 7.110.000. Bila dibandingkan dengan biaya tanggungan BPJS, rumah sakit memiliki selisih lebih pada unit obat sebanyak Rp. 958.549, radiologi Rp. 1.771.517, dan penunjang diagnostik Rp. 581.852. Untuk penunjang laboratorium, terdapat selisih kurang sebesar Rp. 1.341.276. Simpulan: Pada pengobatan bronkopneumonia anak terdapat perbedaan selisih lebih pada unit obat, radiologi, dan penunjang diagnostik, serta terdapat selisih kurang pada unit laboratorium
\end{abstract}

Kata kunci: bronkopneumonia, perhitungan biaya satuan 
Bronkopneumonia adalah penyakit radang paru-paru, mengenai satu atau beberapa lobi paru, ditandai dengan adanya bercak-bercak infiltrat. Bakteri, virus, parasit, dan jamur merupakan etiologi dari bronkopneumonia. Bronkopneumonia merupakan suatu manifestasi klinik dari pneumonia yang paling umum terjadi di kalangan anak-anak. Penyakit ini, termasuk penyakit infeksi dengan insiden kematian tertinggi di dunia. Tahun 2017, di Indonesia tercatat 447.431 kasus anak bawah lima tahun menderita pneumonia dengan angka kematian mencapai 1.351 kasus. $^{1-3}$

Pemerintah Indonesia menetapkan program Jaminan Kesehatan Nasional (JKN) bagi seluruh warga Indonesia dalam upaya kesejahteraan warga, diselenggarakan oleh Badan Penyelenggara Jaminan Sosial (BPJS) dengan jaminan kesehatan mengacu pada kendali mutu dan kendali biaya. ${ }^{4}$ RSUP Prof. Dr. R. D. Kandou Manado, dalam rencana strategis bisnis periode tahun 20152019 menyebutkan bahwa terdapatnya ketidaksesuaian tarif klaim BPJS dengan unit cost yang menyebabkan terjadinya selisih biaya. ${ }^{5}$

Dalam bidang farmakologi, farmakoekonomi merupakan salah satu cabang ilmu yang mempelajari pembiayaan pelayanan kesehatan. Pembiayaan ini, mencakup bagaimana mendapatkan terapi yang efektif, menghemat pembiayaan, dan meningkatkan kualitas hidup pasien. ${ }^{6}$

Informasi tentang biaya satuan (unit cost) merupakan salah satu infromasi masukan dalam membuat kebijakan pelayanan. Menghitung biaya pengobatan, mencari informasi anggaran, pengendalian biaya, penetapan harga yang berkaitan dengan pengambilan keputusan merupakan tujuan analisis biaya satuan. ${ }^{7}$

Data tentang biaya satuan pada pelayanan medis, khususnya terhadap pengobatan pasien bronkopneumonia anak di RSUP Prof. Dr. R. D. Kandou sampai saat ini belum ada. Penelitian ini bertujuan untuk melakukan perhitungan biaya satuan terhadap pengobatan bronkopneumonia anak.

\section{METODE PENELITIAN}

Jenis penelitian ini ialah observasional retrospektif menggunakan data rekam medik pasien dan clinical pathway di Instalasi Rekam Medis dan Bagian Keuangan RSUP Prof. Dr. R. D. Kandou Manado.

Populasi penelitian ialah semua pasien bronkopneumonia anak yang di rawat di RSUP Prof. Dr. R. D. Kandou Manado dan memenuhi kriteria inklusi. Pengambilan sampel menggunakan metode random sampling dan didapatkan sebanyak 42 sampel. Data yang diambil ialah data sekunder dari data rekam medik dan data keuangan.

\section{HASIL DAN BAHASAN}

\section{Karakteristik Pasien Bronkopneumonia}

Berdasarkan karakteristik pasien bronkopneumonia anak di RSUP Prof. Dr. R. D. Kandou Manado didapatkan jumlah kasus pasien berjenis kelamin laki-laki dan perempuan memiliki perbandingan sama banyak yaitu sebesar $50 \%$. Hasil ini agak berbeda dengan penelitian oleh Kaunang et $\mathrm{al}^{8}$ yang menunjukkan bahwa pasien laki-laki lebih banyak dibandingkan perempuan. Pada penelitian tersebut, karakteristik pasien diambil berdasarkan metode total sampling sedangkan pada penelitian ini digunakan metode random sampling dengan perhitungan sampel minimal. Kaunang et $\mathrm{al}^{8}$ juga mendapatkan frekuensi tertinggi pasien bronkopneumonia terdapat pada kelompok usia 2 bulan sampai kurang dari 12 bulan sedangkan hasil penelitian ini menunjukkan usia 2 sampai kurang dar 12 bulan dan usia 12 bulan sampai kurang dari 24 bulan sama banyak yakni $35,7 \%$. Faktor usia merupakan salah satu faktor risiko terjadinya bronkopneumonia. Hal ini dijelaskan bahwa anak di bawah usia 1 tahun memiliki saluran napas yang lebih sempit sehingga infeksi saluran napas akan lebih mudah terjadi. ${ }^{9}$ Menurut penelitian yang dilakukan oleh Hartati et al, ${ }^{10}$ status gizi dan riwayat pemberian ASI eksklusif juga berpengaruh terhadap faktor usia. 


\section{Gambaran Pengobatan Bronkopneu- monia}

Pengobatan pasien di RSUP Prof. Dr. R. D. Kandou Manado berbeda untuk setiap pasien. Data rekam medik pada kartu pemberian obat memperlihatkan bahwa masingmasing pasien tidak sama dalam mendapat pengobatan; hal ini dapat disebabkan oleh adanya perbedaan respon tubuh terhadap obat. Pada penelitian ini didapatkan adanya perbedaan data pada rekam medik dan data keuangan. Perbedaan yang ditemukan ialah penggunaan obat yang tercatat pada rekam medik berbeda dengan catatan pada data keuangan. Sebagai contoh: data rekam medik mencatat bahwa pasien diberikan ambroxol tetapi tidak tercatat pada data keuangan. Sebaliknya pemberian yang tercatat dalam data keuangan tidak tercatat pada data rekam medik. Berdasarkan hasil ini, diasumsikan bahwa perbedaan antara data keuangan dan rekam medis dapat mengarah ke terjadinya kekeliruan dalam pengelolaan biaya rumah sakit maupun jaminan BPJS.

Pengobatan untuk pasien bronkopneumonia anak di RSUP Prof. Dr. R. D. Kandou Manado terbagi atas obat antibiotik dan nonantibiotik. Antibiotik merupakan salah satu pilihan terapi penyakit bronkopneumonia karena sebagian besar disebabkan oleh bakteri. ${ }^{11}$ Antibiotik dapat menghambat maupun membunuh penyebab penyakit, dengan lima mekanisme kerja, yaitu: mengganggu metabolisme sel mikroba, menghambat sintesis dinding sel mikroba, mengganggu permeabilitas membran sel mikroba, menghambat sintesis protein sel mikroba, dan menghambat sintesis atau merusak asam nukleat sel mikroba. ${ }^{12}$

Hasil penelitian mendapatkan bahwa antibiotik yang digunakan untuk pasien bronkopneumonia anak selama di rawat inap di RSUP Prof. Dr. R. D. Kandou ialah golongan sefalosporin generasi ketiga yaitu sefiksim per oral, sefotaksim intravena, seftriakson intravena, golongan penisilin intravena, golongan aminoglikosid intravena dan salep kulit, kloramfenikol intravena, sulfonamide per oral, isoniazid per oral, dan nistatin per oral. Cara pemberian obat dapat menggambarkan keekonomisan biaya pengobatan. Antibiotik yang paling sering digunakan ialah golongan sefalosporin generasi ketiga meliputi sefiksim sirup $73,8 \%$, sefotaksim injeksi $23,8 \%$, dan seftriakson sebanyak $11,9 \%$. Penggunaan antibiotik sefalosporin generasi ketiga banyak digunakan karena antibiotik ini memiliki spektrum luas yang dapat digunakan untuk pengobatan bronkopneumonia yang belum diketahui penyebabnya. Sefalosporin generasi ketiga jauh lebih aktif terhadap Enterobacteriaceae, termasuk strain penghasil penisilinase. ${ }^{13}$ Banyaknya penggunaan sefiksim sirup berdasarkan data rekam medik yang dilihat pada ringkasan pulang, karena obat ini digunakan untuk pengobatan pulang.

Penggunaan antibiotik berdasarkan clinical pathway yang digunakan di RSUP Prof. Dr. R. D. Kandou Manado untuk bronkopneumonia anak usia $>2$ bulan terbagi menjadi dua lini yaitu lini pertama menggunakan ampisilin ditambah kloramfenikol jika tidak ada perubahan atau perbaikan tanda dan gejala sesuai panduan praktik klinis seperti suhu tubuh, laju pernapasan, sesak, dan batuk. Untuk lini kedua digunakan seftriakson. Hasil penelitian menunjukkan bahwa, dari 42 kasus penderita bronkopneumonia anak, terdapat 18 kasus menggunakan antibiotik gabungan ampisilin dan kloramfenikol, sedangkan untuk penggunaan antibiotik lini dua berdasarkan clinical pathway ialah sebanyak 5 kasus, 15 kasus menggunakan gentamisin, juga penggunaan sulfonamid, nistatin, dan isoniazid masingmasing pada 1 kasus. Untuk terapi antibiotik dari 18 kasus yang diberikan terapi lini pertama, 11 kasus diberikan pula antibiotik sefiksim untuk pengobatan pulang, 3 kasus dengan antibitotik lainnya yaitu nistatin, izoniasid, gentamisin, dan sefotaksim. Jumlah kasus dengan pengobatan lini pertama sesuai clinical pathway tanpa varian pengobatan antibiotik lain ialah 4 kasus. Penggabungan antibiotik bertujuan untuk meningkatkan aktivitas antibiotik. ${ }^{13}$ Pemberian langsung kombinasi ampisilin dan kloramfenikol pada pasien dengan keadaan klinis yang memberat. ${ }^{14}$ 
Untuk 15 kasus $(35,7 \%)$ penderita bronkopneumonia digunakan gentamisin sebagai terapi antibiotik; penggunaan gentamisin pada penelitian ini ialah sebagai terapi empiris. Gentamisin diindikasikan untuk infeksi karena kuman Gram-negatif yang sensitif dan dapat menyebabkan pneumonia. $^{12}$ Sulfonamid merupakan antibiotik yang menghambat metabolisme sel mikroba atau bersifat bakteriostatik berspektrum luas. Golongan sulfonamid yang digunakan ialah sulfadoksin yaitu golongan sulfonamid dengan masa kerja yang panjang (absorbsi cepat, eksresi lambat). ${ }^{12}$

Isoniasid merupakan antibiotik yang bersifat tuberkulostatik dan tuberkulosid dan merupakan lini pertama dalam pengobatan dan pencegahan. ${ }^{12}$ Pada penelitian, pasien yang diberikan isoniazid berdasarkan data rekam medik tidak menunjukkan bukti tuberkulosis dan tidak diperiksa khusus untuk pemeriksaan tuberkulosis, sehingga pemilihan isoniazid diberikan tunggal untuk pencegahan. Nistatin atau antibiotik antijamur juga tercatat dalam penggunaan antibiotik pada penelitian ini. Nistatin merupakan suatu terapi profilaksis alternatif yang tidak menimbulkan efek samping sistemik seperti gangguan hati, digunakan untuk mencegah terjadinya kolonisasi dari jamur pada bronkopneumonia yang disebabkan oleh jamur seperti candida spp dan aspergilus. $^{12}$

Obat non-antibiotik biasanya diberikan sebagai terapi suportif atau simptomatik yang bertujuan untuk mengurangi gejala atau keluhan pasien. Dari hasil penelitian, obat non-antibiotik terbanyak digunakan ialah obat analgetik-antipiretik yang bertujuan untuk meredakan demam sehingga suhu tubuh pasien dapat turun dengan pemberian parasetamol. Adanya pemberian analgetik-antipiretik oleh karena hampir semua pasien bronkopneumonia memiliki gejala demam. ${ }^{11}$

Berdasarkan clinical pathway, pasien bronkopneumonia juga diberikan terapi dengan kortikosteroid yang memiliki aktifitas sebagai penghambat inflamasi yang menekan ekspresi sitokin proinflamasi dan berpotensi mencegah respon inflamasi. ${ }^{15}$
Penelitian yang dilakukan Ardayati et al ${ }^{16}$ tentang pengaruh steroid terhadap lama perawatan pasien menunjukkan bahwa pasien yang diberikan tambahan terapi steroid tidak memiliki perbedaan bermakna terhadap nilai length of stay (lama hari rawat) dibandingkan yang tidak mendapatkan terapi steroid.

\section{Gambaran Biaya Pengobatan}

Biaya satuan ialah biaya yang dihitung untuk setiap satu-satuan produk yang diperoleh dari total biaya dibagi dengan jumlah produk (obat, laboratorium, radiologi, diagnostik elektromedik). Perhitungan untuk biaya satuan per jenis obat sefiksim sirup dari 31 kasus, jumlah pemakaian ialah sebanyak 38 sirup dengan total harga $\mathrm{Rp}$. 950.683 maka untuk biaya satuannya ialah Rp. 950.683 dibagi 38 mendapatkan hasil untuk biaya satuan obat sefiksim sirup Rp. 25.017, selanjutnya obat sefotaksim injeksi dari 10 kasus jumlah obat yang dipakai 79 vial dengan biaya total Rp. 682.732 sehingga didapatkan biaya satuan Rp. 8.642. Gentamisin injeksi dari 15 kasus dengan jumlah penggunaan 67 ampul maka didapatkan hasil Rp. 324.222 dibagi 67 ialah Rp. 4.839. Kloramfenikol injeksi mendapat biaya satuan Rp. 14.045, seftriakson injeksi Rp. 18.304, ampisilin injeksi Rp. 12.478. Besarnya biaya ditentukan berdasarkan jenis obat yang digunakan. Berdasarkan hasil penelitian, pada pengobatan bronkopneumonia banyak digunakan obat bentuk injeksi. Pemberian dalam bentuk injeksi diindikasikan untuk pasien yang tidak adekuat dalam menerima obat tablet. Bentuk injeksi lebih mahal dibandingkan tablet karena besarnya biaya produksi, sehingga biaya yang digunakan lebih besar.

Biaya obat, biaya penunjang laboratorium, biaya penunjang radiologi, dan biaya penunjang elektromedik ialah biaya medis langsung yang dihitung pada penelitian ini. Data rekam medik didapat dari Instalasi Rekam Medik, dan data keuangan dari Bagian Kefarmasian rumah sakit. Biaya total obat atau jumlah biaya obat dari seluruh macam obat, berdasarkan data keuangan obat antibiotik Rp. 5.582.975, 
biaya total obat non-antibiotik Rp. 1.210.668, dan biaya total terapi cairan Rp. 2.028.812, sehingga jumlah keseluruhan biaya obat ialah biaya total antibiotik ditambah biaya total non antibiotik dan biaya total terapi cairan sebanyak Rp. 8.822.455, bila dibandingkan dengan biaya total klaim BPJS Rp. 9.781.004, terdapat selisih lebih bagi rumah sakit yaitu sebanyak Rp. 958.549. Biaya penunjang laboratorium ialah Rp. 28.569.725 bila dibandingkan dengan biaya klaim BPJS Rp. 27.218.449, rumah sakit memiliki selisih kurang sebanyak Rp. 1.351.276, sedangkan untuk penunjang radiologi dan penunjang diagnostik elektromedik masing-masing memiliki selisih lebih Rp. 1.886.817 dan Rp. 581.852.

Pengeluaran biaya terbesar untuk pengobatan ialah pada unit laboratorium, sedangkan pengeluaran biaya terendah pada unit penunjang diagnostik. Pemeriksaan penunjang digunakan untuk menunjang diagnosis suatu penyakit. Pemeriksaan radiologi bronkopneumonia dibutuhkan untuk melihat ada tidaknya bercak infiltrat pada kedua lapang paru sedangkan penunjang diagnostik elektromedik seperti tes kulit hipersensivitas dan obat untuk mencari jika terdapat reaksi alergi. Pada pemeriksaan laboratorium berdasarkan clinical pathway penelitian ini terdapat varian pemeriksaan, yang juga dapat meningkatkan biaya tagihan rumah sakit terhadap pasien. Indikasi adanya pemeriksaan varian pada penelitian ini belum dapat ditentukan oleh peneliti karena butuh wawancara mendalam dengan petugas yang bersangkutan.

Lama hari rawat setiap pasien berdasarkan hasil penelitian ini berbeda-beda, sehingga peneliti menghitung biaya per pasien berdasarkan lama hari rawat. Perhitungan dimulai dengan mengelompokkan pasien berdasarkan lama hari rawatnya, kemudian menghitung biaya satuan per unit (obat, penunjang laboratorium, penunjang diagnostik elektromedik, penunjang radiologi) dengan cara jumlah seluruh biaya per unit dibagi dengan jumlah pasien. Setelah mendapat biaya satuan per unit, ditotalkan jumlah seluruh unit. Hasil penelitian menunjukkan biaya per hari rawat berbeda-beda hal ini disebabkan oleh jumlah penggunaan obat yang berbeda pada setiap pasien. Biaya per pasien tertinggi pada pasien dengan lama rawat 11 hari $\mathrm{Rp}$. 4.935.131. Tingginya biaya pada pasien dengan 11 hari rawat disebabkan oleh banyaknya biaya pemeriksaan penunjang laboratorium yang mencapai biaya $\mathrm{Rp}$. 4.050.000. Banyaknya biaya pemeriksaan penunjang laboratorium oleh karena tingginya harga yang ditetapkan pada biaya per satuan jenis pemeriksaan laboratorium, bila dibandingkan dengan penghitungan biaya per jenis pemeriksaan CRP ialah Rp. 128.188 tetapi untuk tagihan pada pasien dengan 11 hari rawat inap untuk pemeriksaan CRP Rp. 327.600. Demikian pula dengan pemeriksaan laboratorium lain yang digunakan oleh pasien ini seperti darah rutin pada penghitungan biaya satuan per jenis pemeriksaan Rp. 59.389 tetapi untuk pasien ini biaya untuk sekali pemeriksaan darah rutin Rp. 134.400. Selain adanya peningkatan biaya dari harga satuan, menurut peneliti ini disebabkan oleh banyaknya varian jenis pemeriksaan laboratorium yang digunakan. Indikasi banyaknya varian pemeriksaan ini dapat diketahui bila ada wawancara langsung dengan petugas yang bersangkutan.

Dari hasil penelitian untuk unit obat ditemukan bahwa terdapat 4 kasus mirip dengan clinical pathway yaitu penggunaan antibiotik lini pertama (kombinasi ampisilin dan kloramfenikol), pemberian analgetikantipiretik, dan lain-lain yang mencakup pemberian terapi cairan, mukolitik, dan bronkodilator. Untuk perhitungan biaya satuan unit obat pada 4 kasus ini berdasarkan rumus biaya total dibagi jumlah produk/ jasa maka perhitungannya Rp. 940.081 bagi 4 biaya satuan obat Rp. 235.020

Menurut peneliti, dengan melihat biaya satuan perjenis obat maupun penunjang dapat menghitung kisaran harga berdasarkan clinical pathway yang ada. Pada hari pertama dari clinical pathway disarankan untuk melakukan pemeriksaan penunjang radiologi dan laboratorium yang mencakup pemeriksaan darah rutin, analisis gas darah, C-reaktif protein (CRP), gula darah sewaktu 
(GDS), kultur darah, dan pemeriksaan laju endap darah, serta pengobatan yang disarankan untuk usia $>2$ bulan antibiotik lini satu atau lini dua, kortikosteroid, antipiretik-analgetik, dan terapi lainnya. Berdasarkan biaya satuan pemeriksaan laboratorium yang ada dan sesuai dengan clinical pathway ialah pemeriksaan CRP, darah rutin, dan GDS. Dari data biaya satuan yang ada, dapat ditarik harga untuk pemeriksaan radiologi Rp. 241.765, pemeriksaan laboratorium CRP Rp. 128.188, darah rutin $\mathrm{Rp}$. 59.389, dan GDS Rp. 41.575, sehingga jumlah pemeriksaan penunjang Rp. 470.917 yang bila dibandingkan biaya satuan laboratorium pada 42 kasus yang ada Rp. 732.557 maka dapat menghemat biaya Rp. 261.640.

Begitu juga dengan penggunaan obat berdasarkan clinical pathway tanpa melihat terapi lain-lain, bila dihitung berdasarkan biaya satuan per jenis obat, maka untuk ampisilin injeksi Rp. 12.478, kloramfenikol injeksi Rp. 14.045, seftriakson injeksi Rp. 18.304, analgetik-antipiretik (parasetamol sirup) Rp. 4.663, dan kortikosteroid (deksametason) Rp. 2.188. Untuk pasien dengan pengobatan lini satu ampisilin tunggal maka biaya ialah Rp. 19.259, pasien pengobatan lini satu kombinasi ampisilin dengan kloramfenikol Rp. 33.304, dan untuk pasien pengobatan lini dua seftriakson Rp. 25.155.

Biaya yang dihitung ialah biaya taksiran menurut peneliti berdasarkan clinical pathway dan biaya satuan per jenis. Biaya dapat bertambah tergantung jenis obat dan berapa banyak obat yang digunakan serta jenis pemeriksaan penunjang yang dibutuhkan dilihat dari keadaan klinis pasien. Obat yang digunakan untuk setiap pasien dapat berbeda-beda oleh sebab adanya keragaman respon tubuh terhadap pengobatan.

\section{SIMPULAN}

Berdasarkan hasil penelitian ini dapat disimpulkan bahwa perbedaan biaya obat bergantung jenis obat yang diberikan. Dari perhitungan biaya ini, data yang dihitung ialah dari data keuangan, namun terdapat beberapa perbedaan data penggunaan obat antara data rekam medis dan data keuangan.
Banyaknya biaya laboratorium mengakibatkan peningkatan jumlah biaya, yang bila dilihat dari clinical pathway tidak semua pemeriksaan laboratorium harus diberikan.

Total biaya satuan rata-rata per pasien ialah Rp. 1.480.631. Tingginya biaya rawat pada 11 hari rawat disebabkan banyaknya pemeriksaan laboratorium dan tingginya biaya satuan per jenis pemeriksaan yang ditagih untuk pasien dengan 11 hari rawat.

Bila dibandingkan dengan klaim BPJS, maka untuk biaya total per satuan unit terdapat selisih lebih pada unit obat, radiologi, dan penunjang diagnostik, sedangkan untuk penunjang laboratorium terdapat selisih kurang. Untuk per hari rawat pasien, pada hari rawat 2, 3, dan 4 terdapat selisih lebih, sedangkan untuk hari rawat 5 hari, 6 hari, 7 hari, dan 11 hari terdapat selisih kurang.

\section{SARAN}

Disarankan untuk penelitian lanjutan agar dapat memberikan lebih banyak masukan ke rumah sakit dalam proses evaluasi upaya perbaikan kebijakan pelayanan.

Penelitian yang dilakukan hanya menggunakan penghitungan biaya satuan pada biaya medis langsung. Perlu pengembangan penelitian dengan menghitung biaya tidak langsung untuk menggunakan metodemetode dalam studi farmakoekonomi.

Tidak adanya wawancara mendalam dengan petugas yang bersangkutan membuat peneliti tidak dapat menentukan indikasi pemeriksaan varian pada pemeriksaan penun-jang, sehingga disarankan untuk penelitian selanjutnya agar peneliti dapat mewawancarai petugas yang bersangkutan.

Untuk perbedaan data antara data keuangan dan data rekam medik, diharapkan dapat menjadi bahan evaluasi bersama agar pada penelitian selanjutnya data yang dipakai tidak terdapat perbedaan dan perhitungan biaya menjadi lebih baik.

\section{DAFTAR PUSTAKA}

1. Behrman RE, Kliegman R, Arvin AM. Pneumonia. Charles G, penyunting. Nelson Ilmu Kesehatan Anak Vol. 2 
(15th ed). Jakarta: EGC, 2000; p. 883-9.

2. Fadhila A. Penegakan diagnosis dan penatalaksanaan bronkopneumonia pada pasien bayi laki-laki berusia 6 bulan. Medula. 2013;1(2):1-10.

3. Kementerian Kesehatan Republik Indonesia. Data dan informasi profil kesehatan Indonesia 2017. 2018 [cited 2018 Dec 11]. Available from: http://www. depkes.go.id/resources/download/ pusdatin/profil-kesehatan-indonesia/ Data-dan-Informasi_Profil-KesehatanIndonesia-2017.pdf

4. Kementerian Kesehatan Republik Indonesia. Buku Pegangan Sosialisasi Jaminan Kesehatan Nasional dalam Sistem Jaminan Sosial Nasional. 2013. [cited 2018 Sept 24]. Available from: http://www.depkes.go.id/resources/ download/jkn/buku-pegangansosialisasi-jkn.pdf

5. Kementerian Kesehatan Republik Indonesia Direktorat Jenderal Bina Upaya Kesehatan. Rencana strategis bisnis tahun 2015-2019 RSUP Prof. Dr. R. D. Kandou Manado revisi III. 2016. [cited 2018 Sept 19]. Available from: https://www.rsupkandou.com/assets/ doc/renstra2016.pdf

6. Hidhayanto W. Analisis biaya satuan (unit cost) pelayanan rumah sakit: pentingnya "unit cost", teori biaya, teknik perhitungan, serta kemanfaatannya bagi rumah sakit. 2009. p. 1-39. Available form: https://kupdf.net/.../ perhitunganunit-cost-ruah-sakit_5a3a1c08e2.

7. Rascati KL. Essentials of Pharmacoeconomic (2nd ed). Philadelphia: Wolters Kluwer, 2014; p. 1-8.

8. Kaunang CT, Runtunuwu AL, Wahani AMI. Gambaran karakteristik pneumonia pada anak yang dirawat di ruang perawatan intensif anak RSUP Prof. Dr. R. D. Kandou Manado periode 2013-2015. eCl. 2016;4(2).

9. Garina LA, Putri SF, Yuniarti. Hubungan faktor risiko dan karakteristik gejala klinis dengan kejadian pneumonia pada balita. Global Medical and Health Communica-tion. 2016;4(1).

10. Hartati S, Nurhaeni N, Gayatri D. Faktor risiko terjadinya pneumonia pada anak balita. Jurnal Keperawatan Indonesia. 2012;15(1):13-20.

11. Utsman P. Evaluasi penggunaan antibiotic pada balita penderita pneumonia rawat inap di RSUD Tidar kota Magelang tahun 2016. [Skripsi]. Surakarta: Universitas Muhammadiyah Surakarta; 2017.

12. Departemen Farmakologi dan Terapeutik Fakultas Kedokteran Universitas Indonesia. Farmakologi dan Terapi (5th ed). Jakarta: FKUI, 2012.

13. Yanti YE. Rasionalitas penggunaan antibiotika pada pasien rawat inap balita penderita pneumonia dengan pendekatan metode gyssens di RSUD Sultan Syarif Mohamad Alkadrie Pontianak [Skripsi]. Pontianak: Universitas Tanjungpura; 2016.

14. World Health Organization. Buku Saku Pelayanan Kesehatan Anak di Rumah Sakit. 2008. [cited 2018 Dec 12]. Available from: http://www.searo.who. int/indonesia/documents/97897919477

01-buku-saku-kesehatan-anakindonesia.pdf?ua $=1$

15. Confalonieri M. Kodric M. Santagiuliana M. Longo C. Biolo M. Cifaldi R. et al. To use or not use corticosteroids for pneumonia? A clinician's perspective. Monaldi Arch Chest Die. 2012;77(2): 94-101.

16. Ardayati S, Kurniawan NU, Darmawan E. Pengaruh pemberian steroid sebagai terapi tambahan terhadap rata-rata lama pasien dirawat di rumah sakit dan tanda klinis pada anak dengan pneumonia. Jurnal Farmasi Klinik Indonesia. 2017;6(3):181-9. 